\title{
Cultural History and the History of the Body in German Ancient History
}

\author{
Jan B. Meister \\ jan.meister@geschichte.hu-berlin.de \\ Humboldt-Universität zu Berlin \\ Institut für Geschichtswissenschaften \\ Unter den Linden 6, D \\ 10099 - Berlin \\ Germany
}

\begin{abstract}
This article aims to explain the idiosyncrasies of cultural history as practiced in Germany - or rather the German-speaking world - and to draw attention to some recent developments within the context of this new cultural history among German ancient historians in the specialized field of the history of the body. Several trends of cultural history are discussed. First, historians have been influenced by the history of everyday life, which focuses on small units and different aspects of ordinary life rather than large superstructures of society. Another trend is the growing interest of German historians in methods and theories derived from cultural anthropology. A third trend is the growing interest in feminist history and especially in the construction of gender roles. A special case in this rather broad field of cultural history is the history of the body. To a certain extent, this specialized area of history exemplifies all the problems and opportunities of cultural history.
\end{abstract}

\section{6}

Keywords

Cultural history; History of the body; German historiography.

Received in: 4/21/2013

Approved in: 6/25/2013 
The goal of this article is twofold: ${ }^{1}$ first, to explain the idiosyncrasies of cultural history as practiced in Germany - or rather the German-speaking world ${ }^{2}$ - and, second, to draw attention to some recent developments within the context of this new cultural history in German scholarship in the specialized field of the history of the body. The idiosyncrasies of German ancient history can be illustrated best when viewed from the outside. In 1999, Thomas Späth published an article in the renowned French journal Annales with the intriguing title: "Nouvelle Histoire Ancienne? Sciences sociales et histoire romaine: à propos de quatre récentes publications allemandes" (SPÄTH 1999). With this article Späth was trying to draw his French colleagues' attention to some recent developments in German historiography, which in his opinion could actually be seen as the starting point of a "new Ancient History". This article was written for two reasons. The first is quite obviously that Späth assumed - and probably rightly so - that most French scholars were either unable or unwilling to read often tedious German "Qualifikationsschriften" and were thus unaware of the new approaches being adopted in German scholarship. The second reason is that in the early 1990s some major changes had indeed taken place not just in German ancient history, but in German historiography as a whole.

The four books discussed by Späth are meant to illustrate this change: they are quite diverse in subject but are united by new methods they use and the questions they pose. Egon Flaig's "Habilitationsschrift" about usurpation in the early Principate (FLAIG 1992) attempts to analyze political history as the history of praxis and focuses on the significance of symbols and rituals. By analyzing the symbolic framework that shaped and motivated the actions of different social groups, he develops a completely new approach to political history. Dirk Barghop's PhD thesis "Forum der Angst" (BARGHOP 1994) is the second book discussed by Späth. In contrast to Flaig, Barghop tackles a completely new issue, focusing on senatorial fear as a historical subject. Making extensive use of the theories of the French sociologist Pierre Bourdieu, his study introduces not only new subjects but also new methods to the field of ancient history. ${ }^{3}$ Späth's own book (SPÄTH 1994), focusing on the construction of masculinity in Tacitus, does likewise, applying the methods of gender studies to the field of ancient history before gender had become a mainstream discipline. The last book, Eckhard Meyer-Zwiffelhoffer's PhD thesis "Im Zeichen des Phallus" (MEYER-ZWIFFELHOFFER 1995), also deals with gender. His approach is clearly inspired by Michel Foucault and is a pioneering study of Roman sexual discourse. Each of the books discussed by Späth deals less with historical events or social structures than with different aspects of culture. What Späth calls "new history" can thus be seen as cultural history. And this new cultural history of the 1990s was not limited to ancient history,

\footnotetext{
${ }^{1}$ I am much indebted to Prof. Dr. Fábio Faversani and Prof. Dr. Fábio Joly for their assistance in getting this paper published and to Dr. John N. Dillon for revising the English text. Needless to say, all remaining mistakes are my own.

2 The scientific communities of Austria and Switzerland are closely connected with those in Germany. In what follows, for the sake of brevity, "Germany" will be used pars pro toto for all three countries.

${ }^{3}$ Whether his analysis of senatorial fear is successful is another question; cf. the critical review by Winterling (2000).
} 
but was part of a larger shift in German historiography as a whole - a change that is sometimes labeled the "cultural turn". ${ }^{4}$

Talking about "turns" is always difficult. ${ }^{5}$ If we were to sketch a simplistic outline of the progress of the new cultural history, ${ }^{6}$ it first appeared in Germany in the 1990s (with various forerunners in the 1980s) and stands opposed to "Sozialgeschichte" or social history. German "Sozialgeschichte" was dominant mainly in the 1970s and focused on hard social "facts" and large macro-historical structures. Historians such as Hans Ulrich Wehler or, in ancient history, the late Géza Alföldy with his influential book "Römische Sozialgeschichte" were prominent representatives of this line of thinking (ALFÖLDY 2011). ${ }^{7}$ The "cultural turn" of the 1990s had no one source, nor was it limited to Germany. ${ }^{8}$ Italian "microstoria", with its focus on small units and different aspects of everyday life rather than on large, social super-structures warrants special mention. ${ }^{9}$ But not only in Italy, in Germany too, historians, at first mostly of the modern era, became interested in local history and the history of everyday life. The focus shifted from objective macro-structures to how people perceived these structures on a subjective level in everyday life. ${ }^{10}$ Another trend was the growing interest of German historians in methods and theories of cultural anthropology, which led to the new discipline of historical anthropology (Cf. WINTERLING 2006). ${ }^{11}$ Here, the ancient historian Jochen Martin is a prominent figure. ${ }^{12}$ It is certainly no coincidence that the four books discussed by Thomas Späth as constituting a "new ancient history" were all - in one way or another - connected with Jochen Martin. A third trend was the

118 growing interest in feminist history and especially in the construction of gender roles. This led historians to reflect on how gender, sexuality and the human body are perceived at different times and in different cultures. All these trends can be subsumed under the label "cultural history". Their focus no longer lies on the "hard facts" of society (i.e. the description of its institutions or its political and economic structures) but on its culture - "culture" being understood as the totality of representations, practices and symbols through which human beings perceive and experience the world. This approach opens up a whole new range of questions, as illustrated by Späth's four examples: instead of investigating political events or social structures, Egon Flaig examined rituals and symbols that,

\footnotetext{
${ }^{4}$ A brief sketch of this "turn" and the development of a "new cultural history" in Germany can be found in TSCHOPP; WEBER 2007, p. 72-82.

${ }^{5}$ For an intelligent discussion of different "cultural turns", see BACHMANN-MEDICK 2006, who sees "turns" not so much as a focus on new objects as a focus on new analytical categories.

6 The label "new" is used to set this cultural history apart from the "old" cultural history of the $19^{\text {th }}$ century.

7 WEHLER 1998 offers a discussion of the challenge (and opportunities) cultural history represents with respect to "Sozialgeschichte".

8 The bibliography is vast. For a recent overview see HUMM 2010; more recent monographs and textbooks include: DANIEL 2006; ORY 2007; TSCHOPP; WEBER 2007; TSCHOPP 2008. For a special focus on ancient history see SCHMITZ 2010.

9 For the work of Carlo Ginzburg in the context of the development of cultural history see DANIEL 2006, p. 285-296.

10 For German history of everyday life see LÜDTKE 1989, and for the broader context see DANIEL 2006, p. 298-313.

${ }_{11}$ Theoretical discussions of cultural history and historical anthropology can be found in the journal "Historische Anthropologie", which first appeared in 1993. For a recent overview on the occasion of the $20^{\text {th }}$ anniversary of the journal, see BURSCHEL 2012.

12 Martin influenced the field not only through his publications (the most important of which are collected in MARTIN 2009) but also by institutionalizing historical anthropology as a discipline at the University of Freiburg.
} 
in political practice, could develop a power of their own; Dirk Barghop sought to find an objective way to describe the subjective feeling of fear in the Roman senate; Meyer-Zwiffelhoffer analyzed the sexual discourse of ancient Rome; and Thomas Späth investigated how Romans conceived and constructed gender roles. The broad aspects subsumed under the label "cultural history" vindicate the scholars who argue that an ongoing "cultural turn" is affecting history as a whole.

There are two main objections to doing history this way. The first is that culture as a category describing all sorts of man-made representations and practices can be applied to virtually anything, making cultural history an indefinable discipline. This is true to a certain extent. Often, cultural history is used as one historical subcategory among many, although it is not really clear how cultural history differs, say, from "historical anthropology", "the history of the body", or "gender history". The French scholar Pascal Ory has attempted to define cultural history as the history of symbols, practices and representations. Cultural history should be seen, Ory argues, as one of the three major approaches to history - the other two being political and economic history (ORY 2007, p. 21f.). From this point of view, "historical anthropology", "gender history", and so on are nothing but subcategories of "cultural history". But if we take seriously the implication that culture includes all man-made representations and can be used to describe every way humans make sense of the world surrounding them, then cultural history cannot be viewed merely as a subcategory of history, not even as a very large subcategory, but must be seen as a whole new way of doing history. Ory is well aware of this. ${ }^{13}$ Thus, in his view, political and economic history are different approaches to history, but not different subjects. Indeed, there is also a cultural history of politics, without which one could rightly claim that political history cannot properly be understood; and ancient historians in particular have long seen that economic history must be viewed as at least partly embedded in society: thus, it too is to a large extent cultural history. In this sense, cultural history is not a special subject or a specific method but rather an analytical category applicable to all fields of history.

There remains, however, the second objection raised against cultural history. This objection concerns the methods applied in cultural history: the fact that cultural history is a new approach does not mean it is a new method. Thus, scholars doing cultural history often take an interdisciplinary approach, borrowing theories from anthropologists, sociologists, and others. ${ }^{14}$ This openness, combined with the already rather open definition of what "culture" is, risks turning cultural history into a sort of "anything-goes playground" where scholars can apply fancy theories to all sorts of banalities. To phrase this objection polemically, cultural history at its worst is the complete opposite of "social history", insofar as it focuses only on representations, texts and symbols, completely ignores historical data; it is garnished with random theories from

\footnotetext{
13 See ORY 2007, p. 7-28 for a full discussion on the problem of definitions. That cultural history cannot be seen as a simple subcategory of history is also the approach taken by DANIEL 2006, p. 7-25 in her introduction, "Kulturgeschichte - und was sie nicht ist" ("cultural history - and what it is not").

${ }^{14}$ The interdisciplinarity of cultural history is the main focus of SCHMITZ 2012.
} 
other disciplines but lacks a rigorous historical method. Thus, in one sense, "cultural history" can be used as a label for describing a modern, up-to-date way of doing history, but it can also be used polemically to denounce sophisticated speculation that makes use of random theories from other disciplines and lacks a thorough historical basis. In some cases this criticism may be justified, but that is rather a flaw of individual studies than of cultural history as a whole. Studying culture understood as the totality of man-made representations does not entail jettisoning traditional historical methods and limiting oneself only to lofty speculation. Cultural history should rather be seen as an invitation to use new theories and models in conjunction with traditional methods in order to consider old problems from new perspectives.

Cultural history is a global rather than a German phenomenon. "Kulturgeschichte" may have been practiced in Germany in the $19^{\text {th }}$ century and "classics" like Jacob Burckhardt still prove to be a source of inspiration, but the influences leading to the "cultural turn" in the 80 s and 90 s cannot be seen as a continuous tradition going back to the $19^{\text {th }}$ century, nor are they all homegrown (Cf. HUMM 2010, p. 10f). ${ }^{15}$ German scholarship must be seen as part of a global community that is not limited to a single national discourse, but rather incorporates various influences of different origin. The reception of French post-structuralist philosophers such as Michel Foucault or Pierre Bourdieu played an important role, and cultural anthropology as it is practiced in the English-speaking world has also been influential. Another major issue is feminist history and gender studies, which cannot be reduced to a single national discourse. Thus, in many respects, "cultural history" in Germany today is not all that different from its forms in the English- or the French-speaking world. Yet there are certain national traits that influence the way cultural history is viewed in Germany. On the one hand, national traditions determine the kind of history cultural history sets itself apart from. In Germany, this manifests in an opposition to social history sketched above and - especially in ancient history an opposition to political and constitutional history. ${ }^{16}$ Turning to France, we can see that this opposition is not as prominent on the other side of the Rhine: The influential Annales school has long since turned away from political history and took interest in such things as the history of mentalities at an early date. Cultural history as a history of representations was not really something all that new in France and could be seen as a continuation of French traditions. Accordingly, the French ancient historian Michel Humm stated in a recent article that cultural history as practiced in Germany since the 1990s is actually a "histoire culturelle à la française" (HUMM 2012, p. 11). Thus, although cultural history in France

\footnotetext{
15 For an overview that takes nineteenth-century traditions into account, see TSCHOPP 2008a.

${ }^{16}$ The situation in ancient history is thus slightly different from that in other epochs, where social history in the 1960 s and 1970s was seen as a new paradigm opposed to older forms of political and constitutional history. Such a clear distinction cannot be drawn in ancient history, where constitutional history has always been social history to a certain extent and vice versa. This also means, however, that constitutional and political history have remained areas from which new cultural-historical approaches have attempted to distance themselves. Thus, Flaig's model of the Roman Principate as an "Akzeptanzsystem" (system of acceptance) is presented as a new approach opposed to the constitutional view going back to Mommsen's "Staatsrecht"; see FLAIG 1992, p. 174-207.
} 
and Germany is not remarkably different today, each version stands in different traditions. These national traditions - and that is my second point - not only determine the way cultural history is perceived, that is, whether as something new, foreign or traditional; national traditions also, to a certain extent, determine what subjects are analyzed with the methods of cultural history. It is probably not a coincidence that many studies by ancient historians in Germany over the last several years have focused on the political culture of ancient Rome, building on classical works of German scholarship such as those by Christian Meier, Matthias Gelzer or Theodor Mommsen and viewing their work in a new light. Egon Flaig (2003), Karl-Joachim Hölkeskamp (2004) and Martin Jehne (1995) in particular have studied the rituals and symbols that played a part in the political culture of the Roman republic. Partly as a reaction to Fergus Millar, these studies try to show that, although many republican institutions were "democratic", the culture that made these institutions work was thoroughly aristocratic. Other studies focus on the everyday life and ritual interaction of aristocrats. Several studies have appeared in Germany in the last ten years that investigate the convivium, including those by Elke Stein-Hölkeskamp (2005), Konrad Vössing (2008) and recently Dirk Schnurbusch (2011). The works by Aloys Winterling and Fabian Goldbeck on friendship, patronage and the institution of the salutatio adopt a similar approach: while older studies focused on patronage as a relatively mechanical explanation of how Roman politics worked, Winterling and Goldbeck focus on the symbolic value of friendship (WINTERLING 2008 [= WINTERLING 2009]; GOLDBECK 2010; MEISTER 2013). ${ }^{17}$ Having many "friends" attend your salutatio, so goes the thesis, is not so much an instrument for steering politics as a manifestation of prestige, which can only be understood in the context of Rome's aristocratic culture. Thus, patronage and friendship - major issues in German scholarship since Gelzer - are viewed in a new light.

A special case in the broad field of cultural history is the history of the body. ${ }^{18}$ The history of the body exemplifies all the advantages and disadvantages of cultural history. First of all, the question must be asked: how can the human body have a history? Here again we can see how different national and disciplinary approaches have opened up this new field of history. One important line of thought derives from anthropology. Already in the 1930s, the French social anthropologist Marcel Mauss published an article about "body techniques" (MAUSS 1936), in which he argued that many things we believe are natural about the body are actually shaped by culture. Making use of the immense amount of data he collected during a lifetime of scholarship, he was able to show that the ways people walk, sit, eat and sleep differ significantly in different societies and must therefore be seen as products not of nature but of culture. More than thirty years later, the English anthropologist Mary Douglas took up this idea and developed it further (DOUGLAS 1973, p. 69-87), as did the French sociologist Pierre Bourdieu, ${ }^{19}$ who started his career not as a sociologist but, like Douglas

\footnotetext{
17 NIPPEL 2002 gives an overview of research on Roman friendship and clientele.

${ }_{18}$ For a general introduction, see LORENZ 2000.

19 For Bourdieu's concepts of "Habitus" and "Hexis" see (among others) BOURDIEU 1993, p. 97-156 and
} 
and Mauss, as an anthropologist. Anthropologists and sociologists began to devote their attention to the way bodies are perceived and conditioned, the way they move and are dressed and the way societies deal with bodily handicaps and deformities. Obviously, historians can ask the very same questions.

Anthropology and sociology are one major influence on the history of the body. But, in my opinion, gender studies and the history of sexuality have been more influential. Kenneth Dover's groundbreaking book on Greek homosexuality demonstrated in the late 1970s that the ancient Greeks had no real concept of "homosexuality" but rather thought of sexuality in terms of active and passive roles (DOVER 1978). These results were taken up by Michel Foucault in the second volume of his "Histoire de la sexualité", where Foucault used ancient Greece to demonstrate that sexual practices were not something natural but rather shaped by discourse (FOUCAULT 1984). ${ }^{20}$ The appearance of Foucault's book led to a veritable flood of publications on ancient sexualities, sexual identities and ways of conceiving and forming sexualized bodies in the ancient world. ${ }^{21}$ The growing interest in gender studies, the authority of Foucault and the fact that ancient sexual practices were quite different from modern ones made ancient sexuality a major field of scholarly interest worldwide. Thus, although sexuality is only one aspect of the human body - and not necessarily the most important one - it has been the primary focus of the history of the body in ancient history for the last twenty years. Other aspects, such as the history of medicine, the strange ancient science of physiognomy or the various bodily metaphors used in ancient language, though not completely ignored, have never attained the same popularity as the study of the sexualized body. ${ }^{22}$ Over the last few years, however, the focus has broadened: Philip van der Eijk - Alexander von Humboldt professor at Humboldt University, Berlin - is currently working on a large project dedicated to the history of medicine and the conceptualization of the human body in ancient science and philosophy. ${ }^{23} \mathrm{~A}$ few years ago, Simon Swain edited a large volume on the ancient sophist Polemon and the peculiar art of physiognomy (SWAIN 2007). A stimulating 2004 book by Anthony Corbeill investigated "nature embodied" in ancient Rome, and two years later Matthew Roller (2006) published an important study of Roman dining postures. Other aspects, too, such as the "clothed body", began to attract scholarly attention (CLELAND; HARLOW; LLEWELLYN-JONES 2005). ${ }^{24}$ In France, the history of the body has become a major subject over the last ten years, and several

\footnotetext{
BOURDIEU; WACQUANT 2006, p. 157-175; for a general overview, see KRAIS; GEBAUER 2008.

20 For Rome: FOUCAULT 1984a.

${ }^{21}$ MEYER-ZWIFFELHOFFER 1995 should be seen in this context; cf. for the 1990s (among many others): HALPERIN; WINKLER; ZEITLIN 1990; GLEASON 1995; HALLETT; SKINNER 1997; WYKE 1998; WILLIAMS 1999. The ideals of chastity and sexual renunciation and the influence of these concepts on the body in Late Antiquity is treated by BROWN 1988.

22 Medicine and physiognomics have been explored by BARTON 1994 and VOGT 1999; bodily metaphors are studied by GULDIN 2000; disabled bodies are the subject of GARLAND 1995; a broad focus on the body is taken by PORTER 1999.

${ }^{23}$ For a description of the project "Medicine of the Mind, Philosophy of the Body. Discourses of Health and Well-Being in the Ancient World," see http://www.klassphil.hu-berlin.de/avh-professur (last accessed 01.18. 2013).

${ }^{24}$ Of course, all studies focusing on clothing are concerned with the body in one way or another. Recent studies include EDMONDSON; KEITH 2008; STARBATTY 2010; GHERCHANOC; HUET 2012.
} 
edited volumes dedicated to it have appeared. ${ }^{25}$ French scholars have been attracted primarily to physiognomics and gender, but many other aspects have also received attention, ranging from the interaction of bodies to the symbolic value of scars, the significance of hair or the iconographic relationship of body and armor in attic vase painting. The growing interest of French scholarship can be seen in the fact that the 2013 "Journée de Printemps de la SOPHAU" was dedicated exclusively to the history of the body and attempted to give an overview of the rich scholarship produced in this field. ${ }^{26}$ A recent publication edited by Daniel H. Garrison (2010) gives a good impression of the broad range of themes and approaches that the history of the body incorporates today: the sexualized body is treated alongside questions of birth and death, health matters, divine bodies and the interrelation of body and self. As the book's title implies, it offers a "cultural history of the human body" that exemplifies the diversity and potential of the subject.

To recapitulate: the history of the body, analogously to cultural history in broad terms, cannot be reduced to a national discourse or an isolated discipline. Sociology, anthropology and gender studies all have had a hand in shaping the way the field is studied today. But there is another thing that the history of the body has in common with cultural history: just as "culture" is hard to define, so too is the "body". Most people think they know what a body is, but you will hardly find two who agree on the details. Long discussions are possible on whether hair is actually part of the body, whether the body can be seen separately from clothing or if one should rather speak of the clothed body, and whether what Mauss termed bodily techniques should not rather be viewed as communication or interaction. These are questions that cannot be answered rightly or wrongly; the answers depend on the perspective one chooses. Such questions, however, highlight a major problem with the history of the body. Carolyn Bynum once wrote that "the body" is not really an independent subject: ${ }^{27}$ either the body is biological matter, in which case it has no history, or it is formed and perceived, or even completely constructed, by culture, in which case it is impossible to draw a clear boundary where the history of the body stops and cultural history begins. When scholars like Judith Butler (1993) argue that the body is constructed entirely through performance and discourse, the body becomes a voluntary act that can be nearly anything. Bynum proposed to view the body as connected to three fundamental questions: identity, desire and materiality. The questions of how bodies and identities are interrelated, how desire is conceived only in connection with the body and how we deal with the materiality of the body, especially when bodies age or die, seem central to our perception of bodies (BYNUM 1996, p. $8 \mathrm{ff}) .{ }^{28}$ In a creative misreading of Bynum, one might use these three categories

\footnotetext{
25 Three volumes have thus far been published in the series "Cahiers d'histoire du corps antique": PROST; WILGAUX 2006; BODIOU; FRÈRE; MEHL 2006; DASEN; WILGAUX 2008; for French scholarship on the history of the body, see also MOREAU 2002; GARELLI; VISA-ONDARÇUHU 2010.

${ }^{26}$ The conference proceedings are to be published in a supplement volume of Dialogues de I'Histoire Ancienne; for the program see http://sophau.univ-fcomte.fr (last accessed 06.27.2013).

27 BYNUM 1996; for the citation, p. 1.

${ }^{28}$ Whether a perception of the body is possible that is not formed by discourse is the subject of the reply by SARASIN 1999.
} 
as a loose definition of what we study when we research the history of the body. This is a working definition I personally would agree with, although it cannot really help us answer such questions as whether hair should be seen as part of the body or not. Thus, the body seen as integral to culture focusing on these three aspects - desire, materiality and identity - is much more than the sum of its body-parts and takes into view much larger perspectives. That also implies, however, that the history of the body is not something exotic, distinct from other subjects of history, but intersects traditional fields of research at many points. By focusing on the body and by applying sociological or anthropological theories, we get a better understanding not only of the history of the human body but also - and perhaps even more importantly - of the past societies that shaped those historical bodies and their representations.

Just like cultural history, the history of the body is not a German phenomenon and cannot be understood by considering German scholarship in isolation. That notwithstanding, I would like to point out some major works in this field that have appeared in Germany in recent decades. First, there is the study by Eckhard Meyer-Zwiffelhoffer (1995) already mentioned. This is a book that analyzes the discourses that shaped Roman sexual practices. It is thus a study standing in the tradition of Foucault. Although the body is not his central focus, MeyerZwiffelhoffer nonetheless shows how Roman society deals with bodily desires he is thus preoccupied with one of the three main aspects Bynum deems central to perception of the body. A second study that deserves mention here is a short book published by Lukas Thommen in 2007. It remains today the only handbook covering the whole field of the history of the body in Greek and Roman antiquity. Thommen considers many different aspects, such as medical discourse, the Greek ideal of kalokagathia, bodily training, gender and sexuality, Christian bodies - just to name a few. His monograph remains, however, a handbook of fewer than 150 pages and the treatment is necessarily brief. Apart from this broad overview, several specialized studies have appeared. In 2010, an edited volume appeared in Austria uniting several case studies focusing primarily on ancient athletics and the ideal of kalokagathia (MAURITSCH 2010). Two recent publications by Edith Hummer (2006) and Henning Wirth (2010) both look at left-handedness in antiquity - a subject that previously had never been treated in a monograph. However, especially the study by Wirth - though not without its merits - shows that the history of the body need not necessarily be practiced as cultural history: Many of Wirth's approaches are rather positivistic, gathering the known facts and asking questions such as whether or not Caesar was left handed. ${ }^{29}$

An entirely different, culture-based approach is taken by Dirk Barghop (1994), whose book has been mentioned above. Although his main goal is to study senatorial fear, the human body is central to his theoretical approach. Applying the theories of Pierre Bourdieu to Roman senators, Barghop attempts to analyze the way senators moved, spoke and acted as a class-based "habitus". Through this habitus, Roman senators appeared and acted as embodiments of

${ }^{29}$ Cf. my review of Wirth's book in MEISTER 2011. 
the republic and thereby brought the republic and its institutions to life. The appearance of an emperor, so the argument goes on, was incompatible with this habitus and so led to senatorial fear. Now, although I do not quite agree with this conclusion, I find the idea of applying Bourdieu's theories to Rome and viewing the senate as an embodiment of the old republic very attractive. ${ }^{30}$

This is where I began my own study of the body of the Roman emperor (MEISTER 2012). My main question was how a monarch appears in a society that denies it is a monarchy and pretends it is a republic. If we glance at monarchies in other cultures, we find that being a monarch has much to do with appearances: A king must act as the symbol of the land and the people he rules; he is surrounded by royal pomp; special clothing and ceremonies mark him out as a special body unlike his subjects. Ernst Kantorowicz (1957), in his famous study of medieval and early-modern Europe, pointed out that European kings were perceived as having two bodies: A "body natural", which grows old and dies, and a "body politic", which is the undying embodiment of the royal office. Tudor England developed a complicated theory of these two bodies that are separate and yet inseparable - a theory that in many ways resembles the two natures of Christ. I do not have room here to go into details. The important issue is that such a theory would not have worked in ancient Rome. Roman authors may think of the republic in bodily metaphors, but the corpus rei publicae is something that existed before the appearance of a monarch, and the relationship between this corpus rei publicae and the corpus principis is problematic in a way that would have been unthinkable in late medieval Europe (MEISTER 2012, p. 153192). The same holds true for the way the Roman emperor appeared among his peers. Unlike a real monarch, he was not able to distinguish himself by special clothing or royal ceremonies but had to play a role and act as if Rome were still a republic - instead of appearing as the embodiment of the new monarchy, which would have been the natural course of events, on the contrary, the emperor had at all costs to avoid letting the monarchy become visible. Although the emperor had nearly absolute power, in everyday interaction with his fellow senators he had to keep up the illusion that the republic and its institutions were still alive (MEISTER 2012, p. 109-131; 222-255).

If one takes the theories of Bourdieu and their application to the Roman senate seriously, then such a deliberate act on the part of the emperor was doomed to failure. Bourdieu defines "habitus" as something conceived as true: Roman senators are Roman senators because they act like Roman senators, because they walk, talk and clothe themselves like senators. The emperor, however, is not a senator: even if he acts like a senator, moves and talks like a senator and wears a senatorial toga, he is nonetheless different. His appearance is therefore insincere and his body no longer shows what he actually is; it is conceived as a deceptive body set apart from his actual self. If we recall the three aspects Carolyn Bynum deems central to the human perception of the

${ }^{30}$ For applications of Bourdieu's theories to Roman senators see CORBEILL 2002 (= CORBEILL 2004, p. 107139); MEISTER 2009. 
body - materiality, desire and identity - we can see that in the early empire the connection between the body and identity of the emperor was highly problematic. This problem has left traces in many different sources and sheds new light on old problems concerning the establishment of monarchy in republican Rome. ${ }^{31}$

Just because my own book is the most recent publication on the history of the body in Germany does not mean that that is the end of it. There are many treasures waiting to be discovered or, more precisely, many treasures that have been discovered and are still awaiting publication. Two "Qualifikationsschriften" focusing on the history of the body have been awarded prizes in recent years but still have not been published. The first is the "Habilitationsschrift" of Adrian Stähli (2002) submitted at the university in Zurich in 2002 and awarded the UBS Habilitationspreis in 2003. Stähli is a classical archeologist and currently Loeb Professor at Harvard. His study focuses on nudity in ancient Greece, its perception in European culture and the question of what it can tell us about the aesthetics - ancient and modern - involved. It will surely be of great value to future research. The second study is the "Habilitationsschrift" of Johanna Fabricius (2003) submitted at the University of Göttingen in 2003 and awarded the Bruno-Snell prize in 2005. Like Stähli, Fabricius is classical archeologist and currently professor at the Free University, Berlin. Her work offers a comparison of how human bodies were conceived in Greece and Rome, adopting a broad approach that takes into account not only iconographic representations but also linguistic and literary aspects. ${ }^{32}$ Her study will therefore most likely be of great

126 interest not only to archeologists but also to ancient historians and classical philologists. To draw to a close, then, the history of the body within the context of cultural history is perhaps not the central focus of German scholarship but it nonetheless has led to several new studies over the last few years and will hopefully continue to do so in the future.

\section{Bibliographical references}

ALFÖLDY, Géza. Römische Sozialgeschichte. Stuttgart, 2011 (4th ed.) [The Social History of Rome. London, 1985].

BACHMANN-MEDICK, Doris. Cultural Turns. Neuorientierungen in den Kulturwissenschaften. Hamburg, 2006.

BARGHOP, Dirk. Forum der Angst. Eine historisch-anthropologische Studie zu Verhaltensmustern von Senatoren im römischen Kaiserreich. Frankfurt, 1994.

BARTON, Tamsyn S. Power and Knowledge. Astrology, Physiognomics, and Medicine under the Roman Empire. Ann Arbor, 1994.

BODIOU, Lydie, FRÈRE, Dominique; MEHL, Veronique (eds.). L'expression des

${ }^{31}$ Cf. MEISTER 2012, p. 131-153 for Roman literature in general; 192-222 for statues; 249-255 for Tacitus' view on the insincerity of the emperor and 255-270 for Suetonius' redefinition of the undefined bodies of the Roman emperors.

32 A brief outline of this approach can be found in FABRICIUS 2010. 
corps. Gestes, attitudes, regards dans I'iconographie antique. Rennes, 2006.

BOURDIEU, Pierre. Sozialer Sinn. Kritik der theoretischen Vernunft. Frankfurt, 1993 [Le sens pratique. Paris, 1980].

; WACQUANT, Loïc J. D. Reflexive Anthropologie. Frankfurt, 2006 [Réponses pour une anthropologie réflexive. Paris, 1992].

BROWN, Peter. The Body and Society. Men, Women and Sexual Renunciation in Early Christianity. New York, 1988.

BURSCHEL, Peter. Wie Menschen möglich sind. 20 Jahrgänge "Historische Anthropologie". Historische Anthropologie 20, 2012, p. 152-161.

BUTLER, Judith. Bodies that Matter. New York, 1993.

BYNUM, Caroline. Warum das ganze Theater mit dem Körper? Die Sicht einer Mediävistin. Historische Anthropologie 4, 1996, p. 1-33.

CLELAND, Liza; HARLOW, Mary; LLEWELLYN-JONES, Lloyd (eds.). The Clothed Body in the Ancient World. Oxford, 2005.

CORBEILL, Anthony. Political Movement. Walking and Ideology in Republican Rome. In: FREDRICK, David (ed.), The Roman Gaze. Vision, Power, and the Body. London, 2002, p. 182-215.

Nature Embodied. Gesture in Ancient Rome. Princeton (N. J.), 2004.

DANIEL, Ute. Kompendium Kulturgeschichte. Theorien, Praxis, Schlüsselwörter. 5th ed. Frankfurt, 2006.

DASEN, Véronique; WILGAUX, Jérôme (eds.). Langages et métaphores du corps dans le monde antique. Rennes, 2008.

DOUGLAS, Mary. Natural Symbols. Explorations in Cosmology. 2nd ed. London, 1973.

DOVER, Kenneth J. Greek Homosexuality. London, 1978.

EDMONDSON, Jonathan; KEITH, Alison (eds.). Roman Dress and the Fabrics of Roman Culture. Toronto, Buffalo and London, 2008.

FABRICIUS, Johanna. Soma/corpus. Körperbild und Körperkonzepte in der griechischen und römischen Kultur. Habil. Göttingen, 2003 (unpublished) [non vidi].

Natürlich oder konstruiert? Körper und Sprache in Griechenland und Rom. Raumwissen 2, 2010, p. 18-21.

FLAIG, Egon. Den Kaiser herausfordern. Die Usurpation im römischen Reich. Frankfurt, 1992.

Ritualisierte Politik. Zeichen, Gesten und Herrschaft im Alten Rom. Göttingen, 2003.

FOUCAULT, Michel. Histoire de la sexualité. Vol. 2: L'usage des plaisirs. Paris, 1984. 
. Histoire de la sexualité. Vol. 3: Le souci de soi. Paris, 1984a.

GARELLI, Marie-Hélène; VISA-ONDARÇUHU, Valérie (eds.). Corps en jeu. De I'Antiquité à nos jours. Rennes, 2010.

GARLAND, Robert. The Eye of the Beholder. Deformity and Disability in the Graeco-Roman World. 2nd ed. 2010. London, 1995.

GARRISON, Daniel H. (ed.). A Cultural History of the Body in Antiquity. Oxford and New York, 2010.

GHERCHANOC, Florence; HUET, Valérie (eds.). Vêtements antiques. S'habiller, se déshabiller dans les mondes anciens. Arles, 2012.

GLEASON, Maud W. Making Men. Sophists and Self-Presentation in Ancient Rome. Princeton (N. J.), 1995.

GOLDBECK, Fabian. Salutationes. Die Morgenbegrüßungen in Rom in der Republik und der frühen Kaiserzeit. Berlin, 2010.

GULDIN, Rainer. Körpermetaphern. Zum Verhältnis von Politik und Medizin. Würzburg, 2000.

HALLETT, Judith P.; SKINNER, Marilyn B. (eds.), Roman Sexualities. Princeton, (N. J.) 1997.

HALPERIN, David M.; WINKLER, John J.; ZEITLIN, Forma I. (eds.). Before Sexuality. The Construction of Erotic Experience in the Ancient Greek World. Princeton (N. J.), 1990.

HÖLKESKAMP, Karl-Joachim. Rekonstruktionen einer Republik. Die politische Kultur des antiken Rom und die Forschungen der letzten Jahrzehnte. München, 2004. [Reconstructing the Roman Republic: An Ancient Political Culture and Modern Research. Princeton (N. J.) 2010].

HUMER, Edith. Linkshändigkeit im Altertum. Zur Wertigkeit von links, der linken Hand und Linkshändern in der Antike. Tönning, 2006.

HUMM, Michel. Histoire culturelle et histoire sociale. Saeculum 60, 2010, p. 187-204.

JEHNE, Martin (ed.). Demokratie in Rom? Die Rolle des Volkes in der Politik der römischen Republik. Stuttgart 1995.

KANTOROWICZ, Ernst Hartwig. The King's Two Bodies. A Study in Mediaeval Political Theology. Princeton (N. J.), 1957.

KRAIS, Beate; GEBAUER, Günter. Habitus. 2nd ed. Bielefeld, 2008.

LORENZ, Maren. Leibhaftige Vergangenheit. Einführung in die Körpergeschichte. Tübingen, 2000.

LÜDTKE, Alf (ed.). Alltagsgeschichte. Zur Rekonstruktion historischer Erfahrungen und Lebensweisen. Frankfurt, 1989.

MARTIN, Jochen. Bedingungen menschlichen Handelns in der Antike. 
Gesammelte Beiträge zur historischen Anthropologie. Hrsg. von Winfried Schmitz. Stuttgart, 2009.

MAURITSCH, Peter (ed.). Körper im Kopf. Antike Diskurse zum Körper. Graz, 2010.

MAUSS, Marcel. Les techniques du corps. Journal de Psychologie Normale et Pathologique 32, 1936, p. 271-293.

MEISTER, Jan B. Adventus und Provectio. Aristokratisches Prestige, Bindungswesen und Raumkonzepte im republikanischen und frühkaiserzeitlichen Rom. Museum Helveticum 70, 2013, p. 33-56.

Der Körper des Princeps. Zur Problematik eines monarchischen Körpers ohne Monarchie. Stuttgart, 2012.

H. Review of Wirth, Die linke Hand: Wahrnehmung und Bewertung in der griechischen und römischen Antike (HABES), Stuttgart 2010. Museum Helveticum 68, 2011, p. 241 f.

. Pisos Augenbrauen. Zur Bedeutung aristokratischer Körper in der späten Republik. Historia 58, 2009, p. 71-95.

MEYER-ZWIFFELHOFFER, Eckhard. Im Zeichen des Phallus. Die Ordnung des Geschlechtslebens im antiken Rom. Frankfurt, 1995.

MOREAU, Philippe (ed.). Corps romains. Grenoble, 2002.

NIPPEL, Wilfried. Klientel, Gesellschaftsstruktur und politisches System in der römischen Republik. Humanistische Bildung 21/22, 2002, p. 137-151.

ORY, Pascal. L'histoire culturelle. 2nd ed. Paris, 2007.

PORTER, James I. (ed.). Constructions of the Classical Body. Ann Arbor, 1999.

POST, Francis; WILGAUX, Jérôme (eds.). Penser et représenter le corps dans I'Antiquité. Rennes, 2006.

ROLLER, Matthew. Dining Posture in Ancient Rome. Bodies, Values, and Status. Princeton (N. J.), 2006.

SARASIN, Philipp. Mapping the body. Körpergeschichte zwischen Konstruktivismus, Politik und "Erfahrung". Historische Anthropologie 7, 1999, p. 437-451.

SCHMITZ, Winfried. ÜberGrenzenhinweg. Neuesozial-und kulturwissenschaftliche Ansätze in der Alten Geschichte. Saeculum 60, 2010, p. 205-225.

SCHNURBUSCH, Dirk. Convivium. Form und Bedeutung aristokratischer Geselligkeit in der römischen Antike. Stuttgart, 2011.

SPÄTH, Thomas. Männlichkeit und Weiblichkeit bei Tacitus. Zur Konstruktion der Geschlechter in der römischen Kaiserzeit. Frankfurt, 1994.

Nouvelle histoire ancienne? Sciences sociales et histoire romaine: à 
propos de quatre récentes publications allemandes. Annales. Histoire, Sciences Sociales 54/5, 1999, p. 1137-1156.

STÄHLI, Adrian. Die Körper und seine Bilder: Nacktheit, der männliche Körper und das männliche Begehren in Bildern des 6. und 5. Jahrhunderts v. Chr., Habil. Zürich, 2002 (unpublished) [non vidi].

STARBATTY, Angelika. Aussehen ist Ansichtssache. Kleidung in der Kommunikation der römischen Antike. München, 2010.

STEIN-HÖLKESKAMP, Elke. Das römische Gastmahl. Eine Kulturgeschichte, München, 2005.

SWAIN, Simon (ed.). Seeing the Face, Seeing the Soul. Polemon's Physiognomy from Classical Antiquity to Medieval Islam. Oxford, 2007.

THOMMEN, Lukas. Antike Körpergeschichte. Zürich, 2007.

TSCHOPP, Silvia Serena; WEBER, Wolfgang E. J. (eds.). Grundfragen der Kulturgeschichte. Darmstadt, 2007. (ed.). Kulturgeschichte. Basistexte. Stuttgart, 2008. . Einleitung. Begriffe, Konzepte und Perspektiven der Kulturgeschichte. In: (ed.). Kulturgeschichte. Basistexte. Stuttgart, 2008a, p. 9-32.

VOGT, Sabine. Aristoteles. Physiognomonica. Übersetzt und kommentiert (= Aristoteles, Opuscula VI). Berlin, 1999.

VÖSSING, Konrad (ed.). Das römische Bankett im Spiegel der Altertumswissenschaften. Stuttgart, 2008.

WEHLER, Hans-Ulrich. Die Herausforderung der Kulturgeschichte. München, 1998.

WILLIAMS, Craig A. Roman Homosexuality. Ideologies of Masculinity in Classical Antiquity. 2nd ed. 2010. New York and Oxford, 1999.

WINTERLING, Aloys. Review of Dirk Barghop, Forum der Angst. Eine historischanthropologische Studie zu Verhaltensmustern von Senatoren im römischen Kaiserreich, Frankfurt, 1994. Klio 82, 2000, p. 272-274.

(ed.). Historische Anthropologie. Basistexte. Stuttgart, 2006.

. Freundschaft und Klientel im kaiserzeitlichen Rom. In: Historia 57, 2008, p. 298-316 [= Politics and Society in Imperial Rome. Malden etc., 2009, p. 34-57].

WIRTH, Henning. Die Linke Hand. Wahrnehmung und Bewertung in der griechischen und römischen Antike. Stuttgart, 2010.

WYKE, Maria (ed.). Parchments of Gender. Deciphering the Bodies of Antiquity. Oxford, 1998. 